Maritime Archaeology Graduate Symposium 2020

$22^{\text {nd }}-23^{\text {rd }}$ February 2020. Short Report Series.

doi: https://doi.org/10.33583/mags2020.07

(C) 2020 The Author

\title{
The Use of Remote Sensing for Identifying Coastal Sites in Lebanon
}

\section{Sirine Saad El-Dine Ghiye}

Lebanese University, Branch 3- Tripoli, Art and Archaeology Department, ghsirin@gmail.com

\begin{abstract}
This article addresses how the use of remote sensing data, such as Landsat 8 and Corona imagery, has led to the effective identification of coastal sites of archaeological interest in Lebanon. The use of different types of maps, once georeferenced, can contribute to highlighting the scale of changing coastal landscapes. Through the case studies of Tripoli, Beirut, and Sidon the main factors affecting the in situ preservation of Lebanon's coastal cultural heritage are evaluated and illustrated by combining the aforementioned datasets with historic maps.
\end{abstract}

Key words

Remote sensing; Georeferencing; Lebanese Coast; Landsat 8; Corona Imagery.

\section{Introduction}

There are various factors affecting the preservation of archaeological sites situated near the coast, with urban development, natural disasters, and warfare being the top three causes of impact. Their affects are made evident through the use of remote sensing, as presented here. The results support the 
argument that it is possible to both detect sites but also monitor the changes that occurred at the sites of Tripoli, Beirut, and Sidon over the past 60 years.

There are many Geographic Information Systems available today. In this instance, QGIS was useda free open-source cross platform — which enables one to view, edit, and analyse geospatial data from Tripoli, Beirut, and Sidon, and export the output maps. The focus of this study is the analysis of two different types of satellite imagery, Landsat 8 and Corona imagery. These are combined and georeferenced historic maps made by geographers and travellers. This has allowed the current state of the archaeological sites of Tripoli, Beirut, and Sidon and the adjacent landscape 'through the eyes' of remote sensing to be showcased and the changes that took place during the past 60 years to be highlighted. In effect, this juxtaposition of new and old maps enabled the changes and the factors affecting each site to be monitored and suggest a monitor strategy to save and protect these sites in case if it's not destroyed yet. To successfully address this, the study first provides information pertaining to Lebanon's modern history, aiming to place emphasis on the factors affecting the country's coastal and maritime archaeology, and to argue that both Underwater Cultural Heritage $(\mathrm{UCH})$ and the adjacent coastal landscape are currently under threat. The methodology is presented, along with the results of the analysis of the historic maps, Corona, and Landsat 8 imagery. Finally, the emerging observations for each site are discussed.

\section{Lebanon's maritime heritage and thalassocracy}

Lebanon is a country facing the Mediterranean Sea in Western Asia, with its coastline stretching from north to south for approximately $220 \mathrm{~km}$ (Fig. 1). It has a strategic geographic position between occidental and oriental countries, and it has played an important role in trade and exchange for thousands of years.

Lebanon has a rich and diverse heritage, having been inhabited by multiple civilizations and cultures, with the archaeological record dating back to prehistoric times. Lebanese archaeology has been associated with the Phoenician civilisation that ruled the entire country, and is said to have established independent city-states, primarily along the Mediterranean coast (Mark, 2018). The Phoenicians (Fig. 2) thalassocracy had a profound impact on the history of the Mediterranean more broadly, lasting more than a thousand years (1550-300 BC). Through their renowned merchants and trading activities, they developed wealthy city states, such as those examined here: Byblos, Tyre, and Sidon (Llewellyn-Jones, 2018, 68). 
Scholars argue that one of the reasons behind Phoenician success was the dynamic and yet accessible coastal landscape of the country, characterized by a succession of natural basins and bays. This geomorphological characteristic contributed to the Phoenician thalassocracy flourishing, as mariners were sheltered from the dominant winds and protected from storms and currents. Evidence of this is the small and yet wide bays of St Georges in Beirut (Fig. 3), as well as other sites such as the Jounieh Bay, Chekka Bay, and the Akkar Bay, that all have facilitated and sheltered ancient sailing ships from the dominant south-west winds, allowing mariners to anchor or beach their merchant ships (Sanlaville, 1977: 6). Indeed, there are a lot of anchorages that mariners would have used in ancient times, a characteristic example of this can be seen at the Zireh Island off the coast of Sidon (Fig. 4), where the remains of three large quarry sites suggest it was used as a harbour for the export of stone blocks (Carayon et al., 2011).

\section{Modern development affecting the Lebanon's underwater and coastal cultural heritage}

Following the independence of the country in 1943, Lebanon has witnessed political instability, civil war, and turmoil. The end of The Lebanese Civil War was one of the most devastating conflicts of the country's modern history, lasting roughly 25 years (1975-1990) (Haugbolle Sune, 2011) and almost completely destroyed Beirut and its suburbs. Inevitably, the post-war period saw an intense period of development (Fig. 5), which resulted to in the destruction of archaeological sites both on land and under water due to uncontrolled rapid urban development. This is especially evident at some of the larger sites, such as Tripoli, Beirut, and Sidon and hence the reason for their being chosen for this study.

More recently, during the past ten to twenty years, the country has passed into a different phase in its modern history. It has witnessed a second phase of radical change in development and urbanisation as it tries to answer the call resettling millions of Syrian refugees. This means that larger housing and other infrastructures projects are starting to emerge, and on-going discussions suggests that there is much more to be done in the following years to come (Daher, 2015). Inevitably, since the end of the Civil War, the Lebanese coast has been the subject of radical changes and urban development, such as commercial centres, resorts and housing facilities, with this to be expected to last for at least another decade or so. As part of this development and investment, large-scale development plans have been commissioned including the expansion of Beirut International Airport and other harbours as well as other large hotel resorts. These radical developments are of course of great concern to the national heritage agency as large-scale constructions are expected to affect terrestrial and underwater archaeology. To effectively address this, this article focuses on the application and analysis of three 
different types of satellites imagery namely, Landsat and Corona, and historic maps as an attempt to showcase that changes are observable and constitute a real threat to the archaeology of the country.

\section{Landsat satellite imagery:}

Among the multispectral satellite images available with global coverage and free access, those captured by the Landsat program sensors are perhaps the most widely used in the fields of geology and archaeology, with Landsat Thematic Mapper imagery to have been extensively applied for discovery and identification of settlements and sites (Wilkinson \& Tucker 1995, 16-25). It has been characterised as one of the most versatile tools in remote sensing studies, as it enables the studying of landscape conditions (Borie, et all, 2019). The Landsat program have been running since 1972, surveying the earth's surface with a coverage of $185 \times 185 \mathrm{~km}$ per single image (USGS) (cf. Borie, et al., 2019). There are different developed versions of Landsat: in this instance the most recent satellite imagery dataset Landsat 8, which uses 11 bands and produces photography with 30-m resolution was used.

\section{Corona imagery}

Declassified Corona satellite imagery, collected 1960-1972 as part of the world's first satellite intelligence program, provides nearly global, high-resolution, stereo imagery that predates many of the land-use changes seen in recent decades. The Corona program includes more than 860,000 images covering most of the earth's surface (Cassana, 2020). It is already considered an integral resource for the study of ancient landscapes and archaeology, and the declassified data includes extensive coverage of the Middle East (Graham et al., 2002). This data presents a clear image of Lebanon around 19691970, before radical urban development took place. Comparison with the new Landsat 8 images, provides an opportunity to study changes that have taken place in the country the past 60 years in some detail.

\section{Methodology}

Overlaying the datasets reveals the changes that took place between roughly the 1970s to today, underlining the factors threatening the preservation of archaeological sites and the adjacent coastal landscape. To have accurate data, the Corona imagery has been georeferenced in QGIS, which has then been overlaid on the Landsat 8 imagery. The two datasets were aligned with more than 50 common points, or using gridlines, generating a new merged product (Fig. 6).

There are great challenges when georeferencing data, in particular with historic maps, such as the Renan map of 1864 (Fig. 16), that lack a grid system. This makes georeferencing a process of trial and 
error. Despite these problems, the final product is a new georeferenced map that allows changes in the landscape provoked by the above cited factors over the past 50 years to be seen, including those that impact the archaeological remains.

\section{The case studies}

\section{Beirut}

Beirut, the modern-day capital of Lebanon, was an important city in antiquity, with archaeological evidence found in the town centre or Centre Ville ${ }^{1}$ suggesting that it has been occupied since the Palaeolithic (Curvers \& Stuart, 1998-1999: 14; 2005: 191). Beirut is extensively mentioned in ancient sources under different names such as: Brt in Ugaritic; Beruta in Phoenician; Biruúutti in Acadian; and Berytos in Greek. Reference to the city's harbour is common in these ancient texts, where it is described as one of the most active in the Mediterranean. The earliest evidence is found in the Amarna Letters $^{2}$ dating to 1360-1332 BC, with the archaeological record revealing that perhaps the first port infrastructure was developed during the Hellenistic period, and actively used up to Byzantine and Ottoman periods (Jessup, 1910 in Marriner, 2007: 388-389).

At the end of the Civil War in 1990, Beirut was almost completely destroyed. This led to a period of intense and unregulated development covering the ancient ruins of the city leading to the loss of a large area of archaeological remains on land, along the coast, and under the sea. Furthermore, the shape of the coast has changed significantly since 1841 due to geomorphological parameters, erosion, and tectonic activity. The reconstruction of the harbour and the enlargement of the international airport (see Fig. 7, 8) further contributed to the destruction of any coastal and shallow underwater archaeological sites, as modern construction extended the coastal landscape, creating additional land, which currently facilitates the construction of new roads and souks, that are property of a private company. Needless to say, these development plans have led to the destruction of the paleo-coast, and the adjacent submerged archaeology, as the entire project was undertaken without plans to preserve and manage the known archaeological resource. Examples of this include the ancient mole and the two demolished castles of al-Mina and al-Mussala (Fig. 9 and 10). Today the shape of the entire coast is

\footnotetext{
${ }^{1}$ Centre Ville is the common name of the more active area of Beirut, which contains the commercial souks, and new construction built over the archaeological sites.

2 The Amarna Letter are an archive, written on clay tablets, primarily consisting of diplomatic correspondence between the Egyptian administration and its representatives in the other kingdoms.
} 
completely different to that of 100 or even 50 years ago, with ancient remains both on the coast and the adjacent underwater environment being destroyed or buried under the modern capital (Fig. 11).

\section{Tripoli}

Tripoli is the second-largest city in Lebanon with several small islands off its coast. The city is mentioned in various ancient resources with different names and was first mentioned by the Arab geographer Idrisi who is first geographer visited the city during the $12^{\text {th }}$ century AD, the city was founded in the $8^{\text {th }}$ century BC during the Iron Age II period (Salamé Sarkis, 1980; Sartre, 2001: 4142).

The maritime roles of Tripoli have interested many authors, most of whom have neglected to emphasize the pre-existing harbour, which was perhaps destroyed by the tsunami of AD 551 (Darawche et al., 2000, 403-414). This, however, seems to change after the death of Alexander the Great, with the ancient literature suggesting that under Seleucid control, a shipyard was established (Diodorus XIX, 58). According to Roman sources, the city flourished and soon became a naval administration centre with this transition perhaps taking place at some pointunder Hadrian (r. 117138). According to al- Balādhurī (1916: 194-195) Tripoli had a fortified harbour, in the 9th century AD, and its port could accommodate thousands of ships (LeStrange, 1890: 348; Viret, 1999-2000: 124).

Based on a photo taken by pioneer archaeologist Poidebard, who was the first to apply aerial archaeology in the Middle East, the ancient jetties constructed to protect the port against dominant winds where still evident in 1950-1951 (Fig. 12).

This constitutes a clear indication of an important maritime site, with evident infrastructure remaining largely preserved up to the French mandate, where the harbour prospered with intense commercial activity (Deschamps, 1973: 294). Unfortunately, as can be seen in Figure 13, urban development in the early-20th century has completely covered this once-great city of Al-Mina, with modern harbour infrastructures (outlined in red), substantially modifying the site itself, and the wider topography of the adjacent coast. In Figure 13 (area outlined in red), it can be seen that the ancient harbour area has undergone radical changes, with the data showcasing: an area $1.2 \mathrm{~km}$ wide of combined land reclamation and progradation; and the development of a jetty extending $2.2 \mathrm{~km}$, positioned in the northeast of the zone, and the development of a staggering 27 additional quays. To the south of Tripoli, the construction of beach resorts is noticeable, affecting the quays in Qalamoun area, an area which used once used to be part of the classical city of Calamos (Gubel, 1992c: 367) (Fig. 13, marked in orange). 


\section{Sidon}

Similar to Beirut and Tyre, the port of Sidon is mentioned in ancient sources: in the Ebla archives 23rd century BC, the Ras Shamra documents, the Al-Amarna letters, as well as the story of Wenamun dating to the Iron Age I. The Bible describes Sidon in several passages and it seems to have received its name from the first-born of Canaan, the grandson of Noah (Genesis, 10:15, 19).

Sidon had an important maritime role in antiquity, as attested in royal and administrative texts. For examples, under Salmanasar III (858-824 BC), the Assyrian text mentioned the transportation of the tribute of Tyre and Sidon by boat. Probably dated from the reign of Teglath-Phalasar III (744-727 BC), the Nimrud document mentioned the port of Sidon under the Assyrian administration. A relief from Nineveh $^{3}$ represents King Luli escaping from the port of Sidon to Cyprus (Barnet, 1969).

Five natural ports that might have been used in antiquity have been identified in Sidon (Fig. 14): the northern harbour (1), the northern port which is also the current port of Saïda (2), the island port of Ziré (3), the 'round cove' (4), and the mouth of the Nahr el-Aouali (5) (Carayon, 2013).

Remote sensing techniques have been applied on the coast of Sidon to identify and locate changes in the landscape over the years. To examine these changes, a Corona map from 1967 was used in conjunction with the Landsat map from 2019 (Fig. 15). Based on this examination, it appears that the coastline has been modified immensely during recent decades. There has been large-scale land reclamation for the construction of roads and buildings, the enlargement of the new harbour, which most certainly is a continuation of the ancient harbours, and new construction around and on the ridge or of the Cirque Ronde, which might have served a harbour activity are noted. And according to these photos, we can suggest that some ancient features have been destroyed. A map made by Ernest Renan in 1863 (Fig. 16) shows Sidon and its natural basins and ancient features. Having used the gridlines available on Google Earth to georeference the map (Fig. 17), changes in the coastline can be identified. The results indicate a modification of the coastline, including the addition of new jetties to expand the harbour, land reclamation to expand the roads, and the construction of restaurants and hotels on the coast, overlaying both historical and archaeological sites.

\section{Discussion}

\footnotetext{
${ }^{3}$ Nineveh was an ancient Assyrian city of Upper Mesopotamia, located on the outskirts of Mosul in modern-day northern Iraq.
} 
From the presented data, it can be seen that radical and to a certain extent unregulated urban development has altered Lebanon's coastal and adjacent underwater landscape to the degree that even the most known and important ancient harbours and port cities greatly modified. This renders the effective monitoring and management of construction works in the country necessary. As it has been displayed above, historic maps, Corona imagery and Landsat 8 satellite data combined present insights into changes in the landscape and the coast. This study suggests that coastal and underwater archaeological sites are under threat and this can be attributed due to the urban development, natural disasters, warfare, and the lack of communication between the archaeological community and other stakeholders with private interests. A solution to this might be that archaeological sites, both coastal and underwater, should be managed and protected before any construction projects take place, by combining the use of remote sensing monitoring, desk-based studies, and rapid appraisal studies. This is made possible because the methodology proposed here using satellite images, historic maps, georeferencing, has the potential to be an important tool for detecting, mapping, and monitoring, thus prioritizing both near coastal and shallow-depth rescue excavation missions.

\section{Acknowledgments}

My sincere gratitude and appreciation to the MAGS committee for their efforts and hard work to deliver a successful symposium. I would also like to express my sincere gratitude to the Honor Frost Foundation for funding my participation at the symposium and for promoting maritime archaeology in Lebanon and for allowing the publication of this article. Sincere thanks to the General Directorate of Antiquities (DGA), and special thanks to the Director Mr. Sarkis Khoury for their constant support. I would like to also thank the Endangered Archaeology in the Middle East and North Africa EAMENA Project for providing training, and special thanks to Dr. Lucy Semaan for mentoring me and supporting me throughout.

\section{References}

Marriner, N., Morhange, C., and Saghieh, M., 2008, Georarcheology of Beirut's ancient harbour, Phoenicia. Journal of archeological Sience 35, 2495-2516.

Goiran, J.-Ph., and Morhange, C., 2001, Geoarcheology of ancient mediterranean harbours: issues and studies, Eng. transl. E. Willcox. Topoï, vol. 11, fasc. 2, 645-667. 
Carayon, N., Morhange, C., and Marriner, N., 2012, Sidon's ancient harbour: natural characteristics and hazards. Archaeology \& History in the Lebanon 34/35, 433-459.

Marriner, N., and Morhange, C., 2005, Under the city centre, the ancient harbour: Tyre and Sidon: heritages to preserve. Journal of Cultural Heritage 6, 183-189.

Carayon, N., 2012-13, Les ports Phéniciens du Liban: milieu naturals, organization spatiale et infrastructure. Archaeology \& History in the Lebanon 36-37, 1-137.

Nour ed-dine, I. and Mior, A., 2018, Archeological survey of the Pheonician harbour at Tyre, Lebanon. BAAL 18, 95-112.

Abu Diwan, G., and Doumet, J., 2017, The Berytus-Heolopolis Baalbeck Road in the Roman Period: A Least Cost Path Analysis. Mediterranean Archaeology and Archaeometry, 17. 3, 225-241.

Traboulsi, F., 2012, A History of Modern Lebanon. Pluto Press.

Philip, G. and Donoghue, D.N.M., Beck, A.R., and Galiatsatos, N., 2002, CORONA satellite photography: an archaeological application from the Middle East. Antiquity 76 (291), 109-118.

Jesse Casana, 2020, Global-Scale Archaeological Prospection using CORONA Satellite Imagery: Automated, Crowd-Sourced, and Expert-led Approaches. Journal of Field Archaeology 45, sup. 1S89100. 


\section{Figures:}

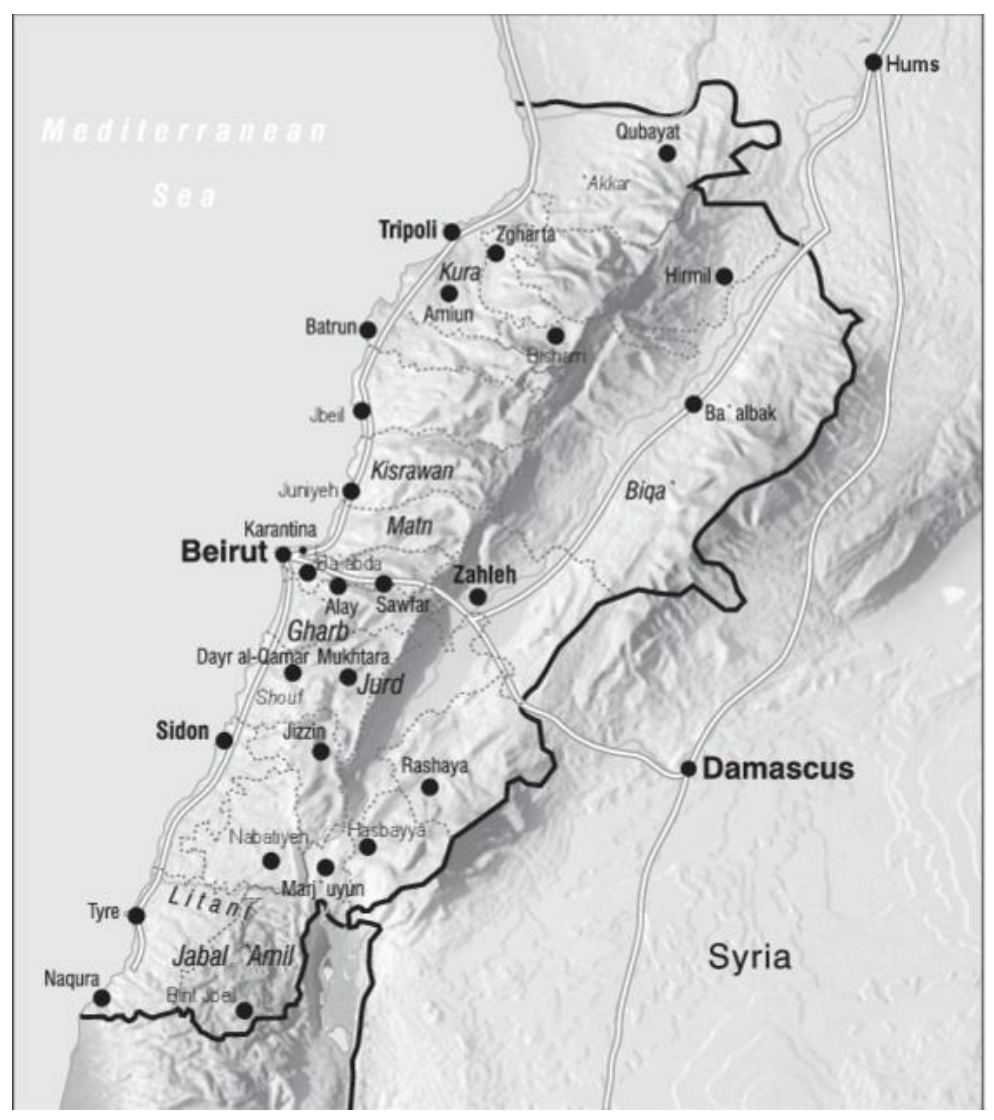

Figure 1. Modern Lebanon

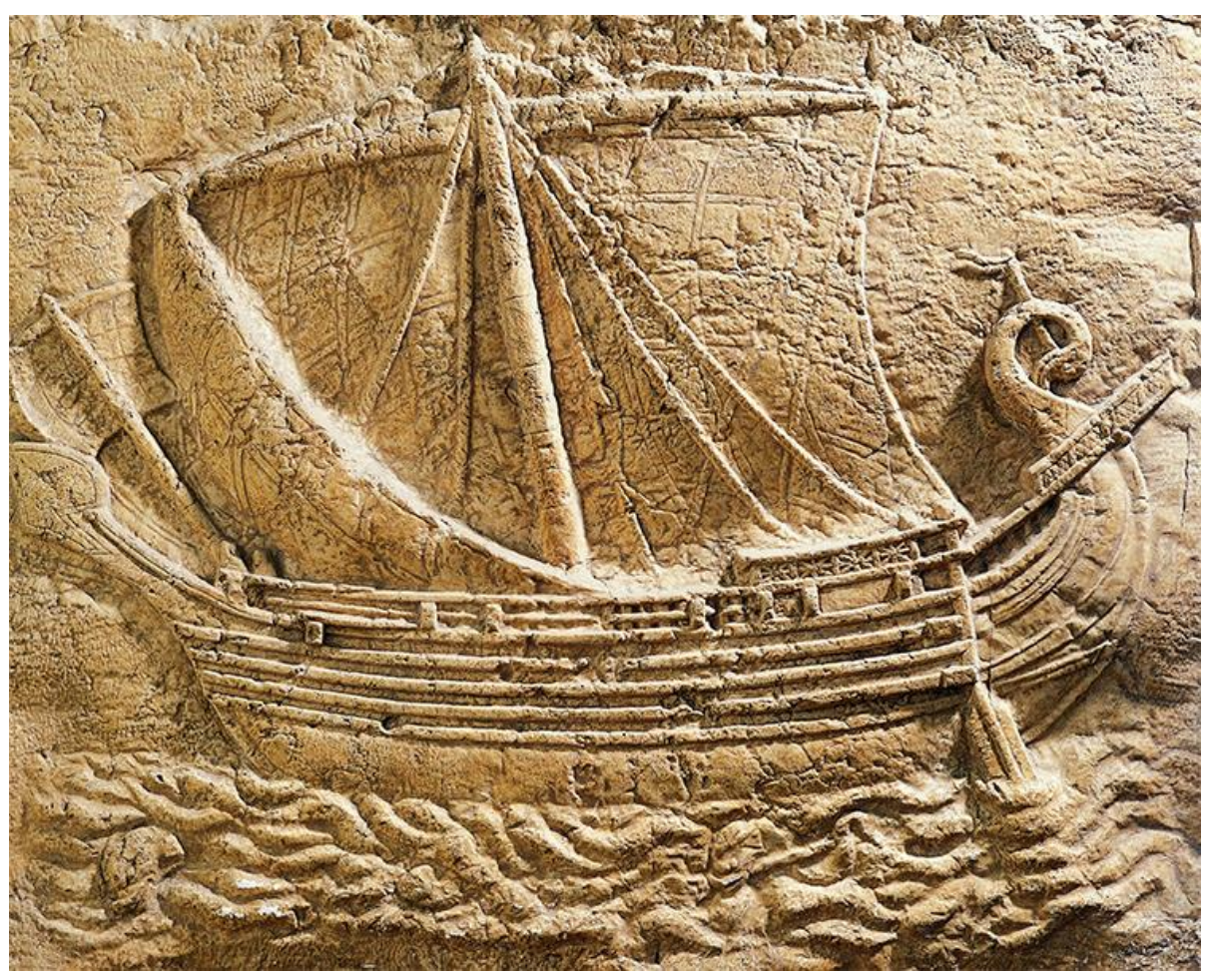

Figure 2. A Phoenician-Punic ship from a relief carving on a 2nd century CE sarcophagus. 


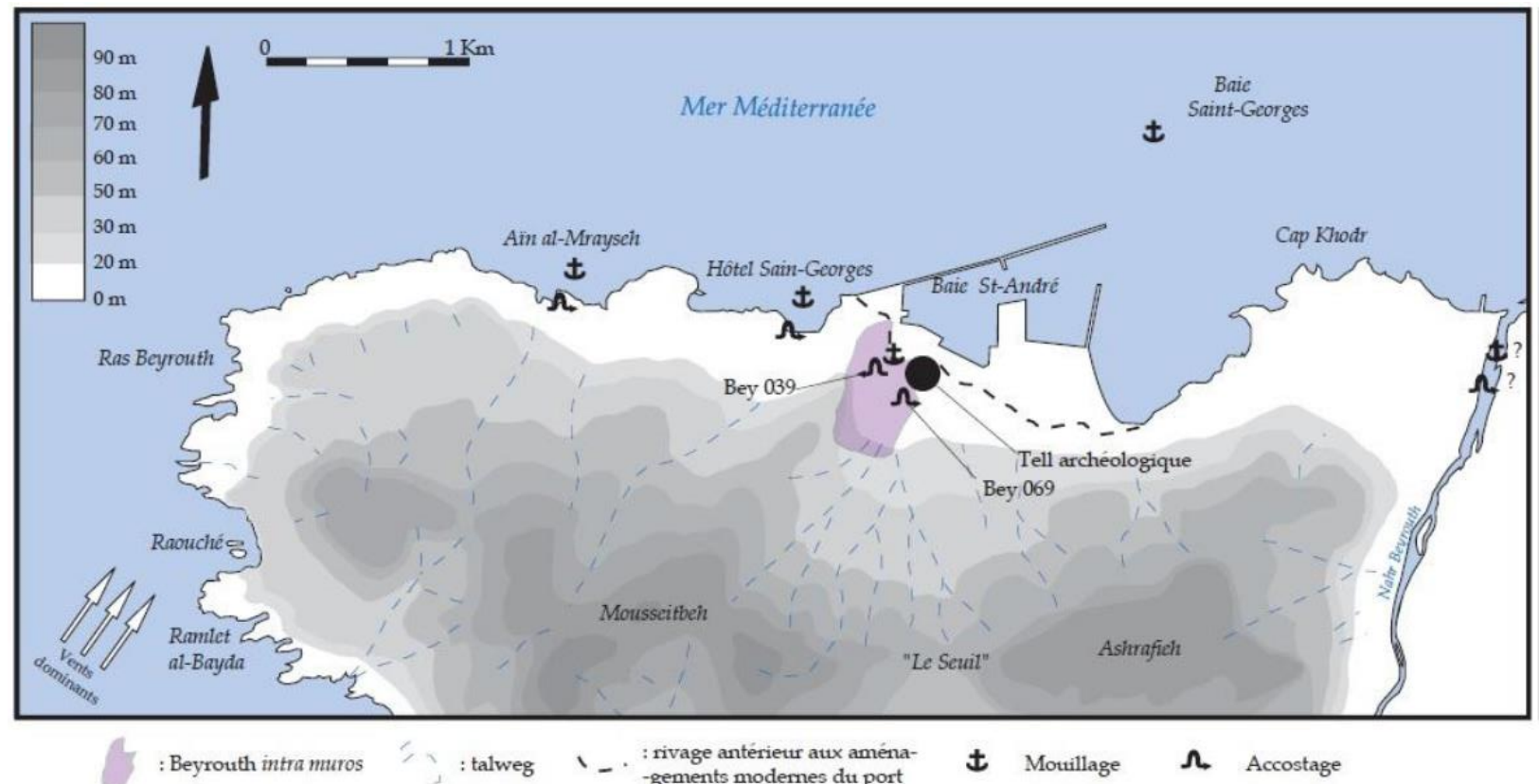

Figure 3. Geomorphology of Ras Beirut with mooring and docking possibilities (De Vaumas, 1946, modified by Carayon, 2008: 939 figure 17.03). 

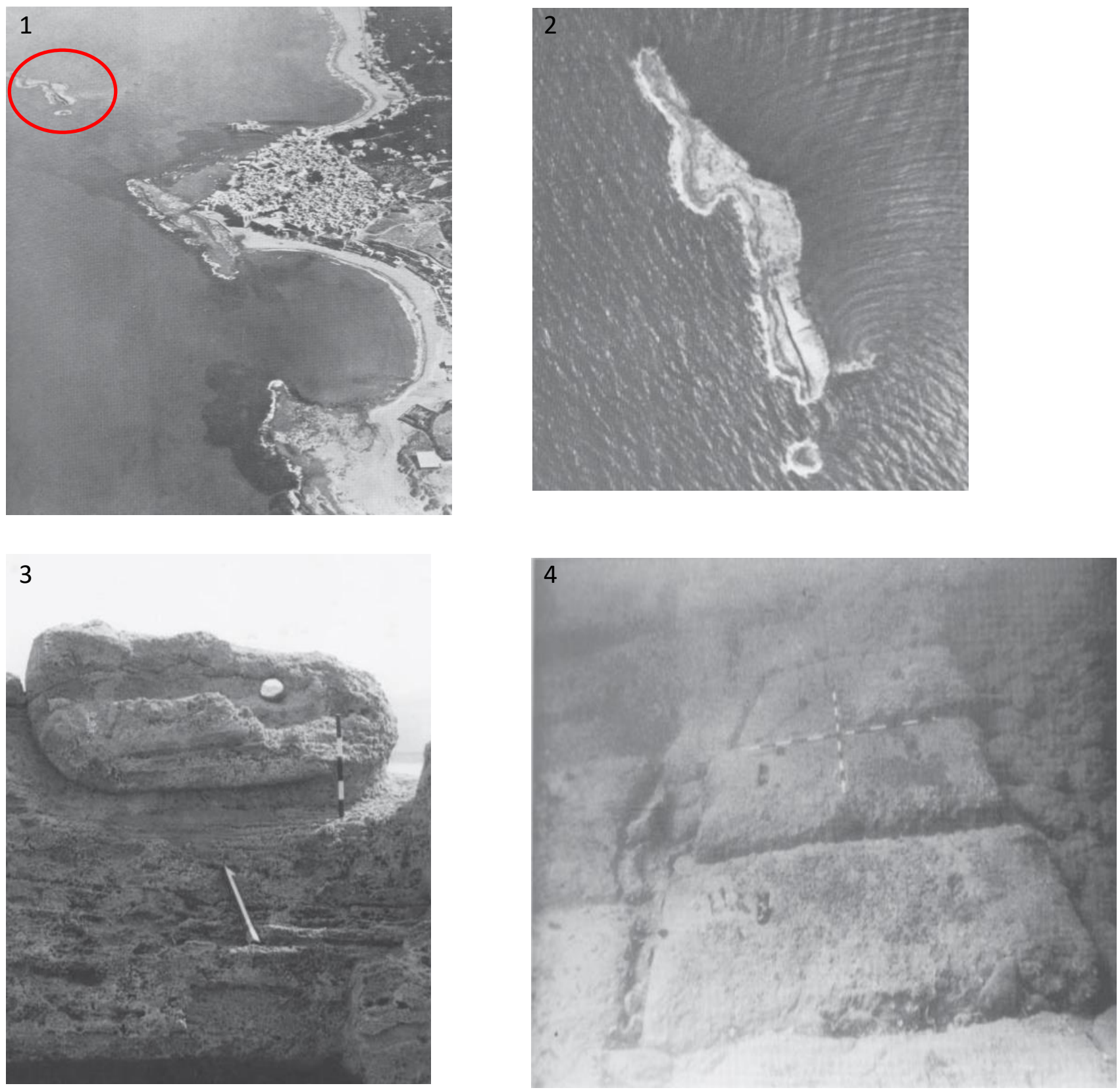

Figure 4. Photos of Zireh taken by Poidebard dating to 1951 show the maritime remains: 1: general view of old Sidon, 2: plan view of Zireh, 3: bollard, 4: jetty foundation 

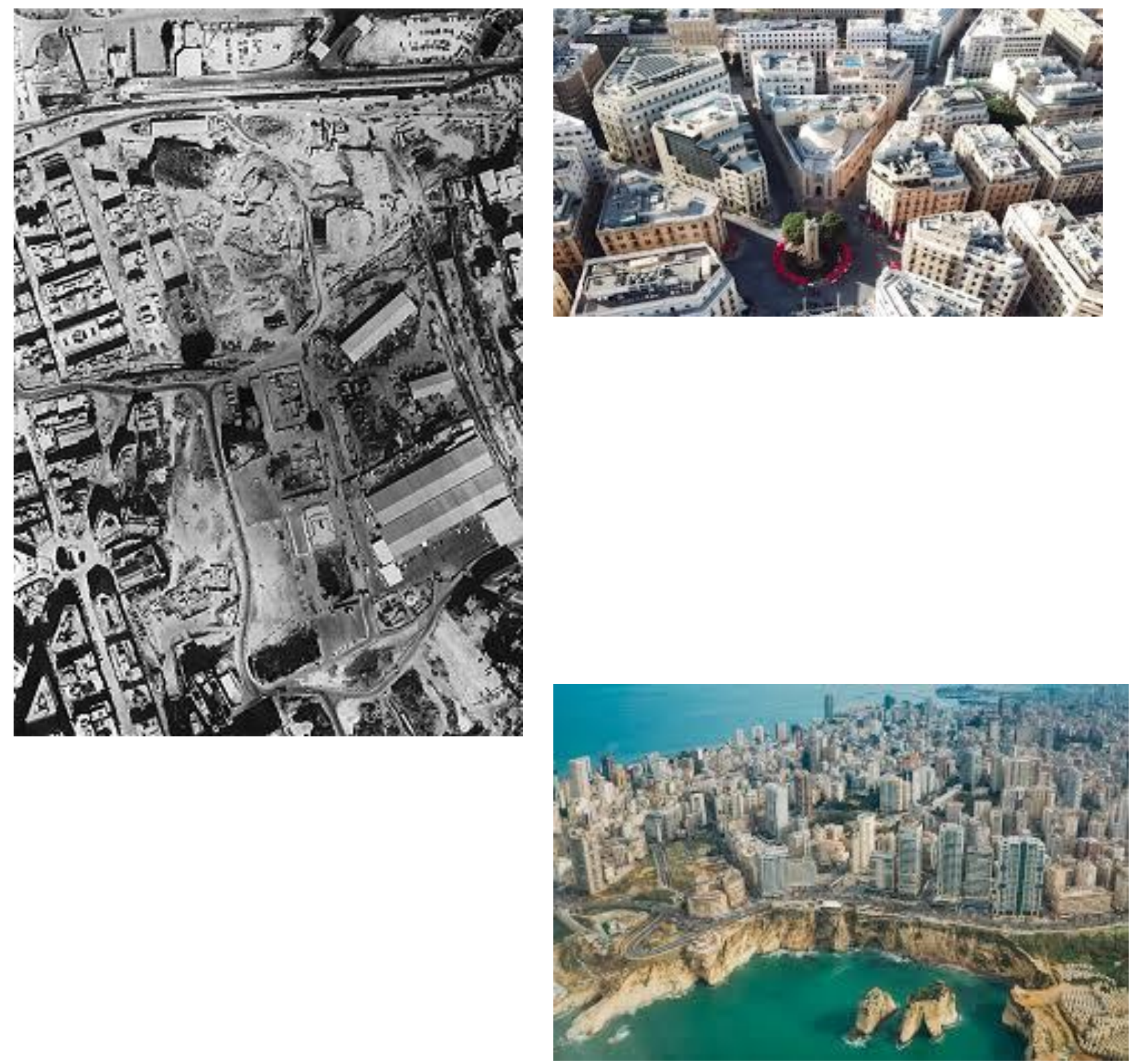

Figure 5. Beirut' changes since the Civil War (left) to today (right) 


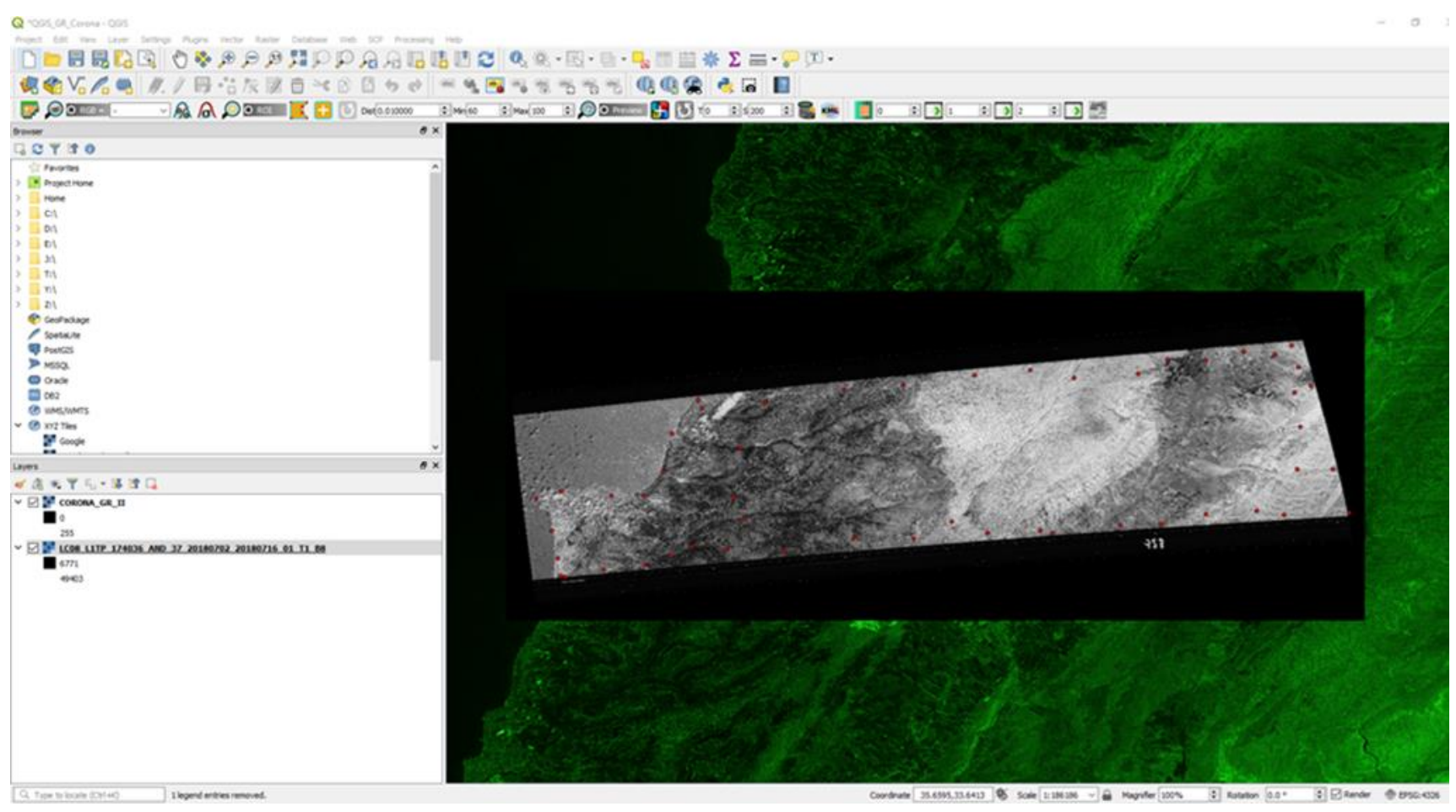

Figure 6.Georeferencing process application in QGIS, using two maps Landsat (below) and Corona (above). For a successful application at least 50 common points (red points) need to be located. 

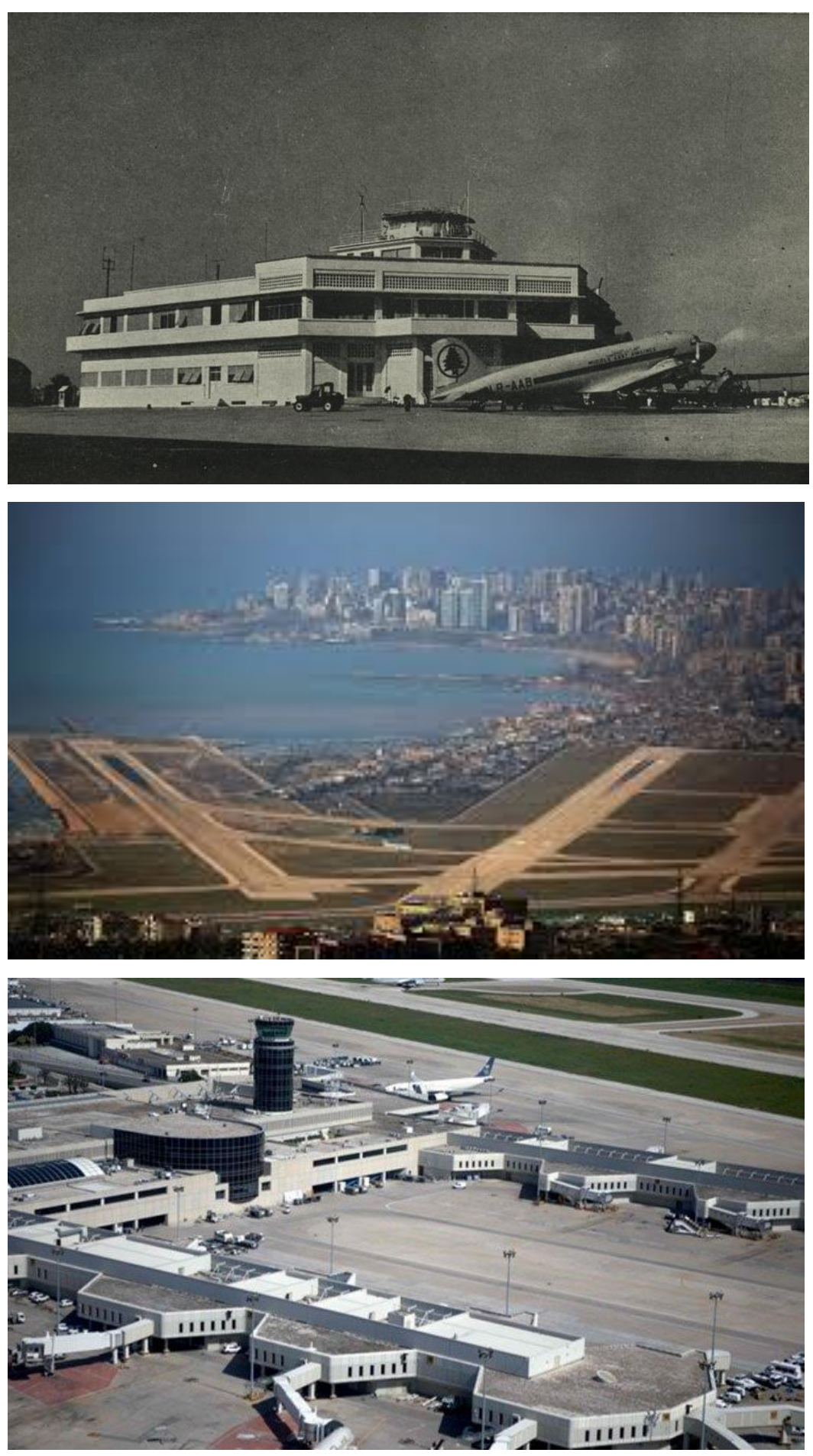

Figure 7. Beirut airport from 1947 to today: restoration and enlargement started in 1991. 

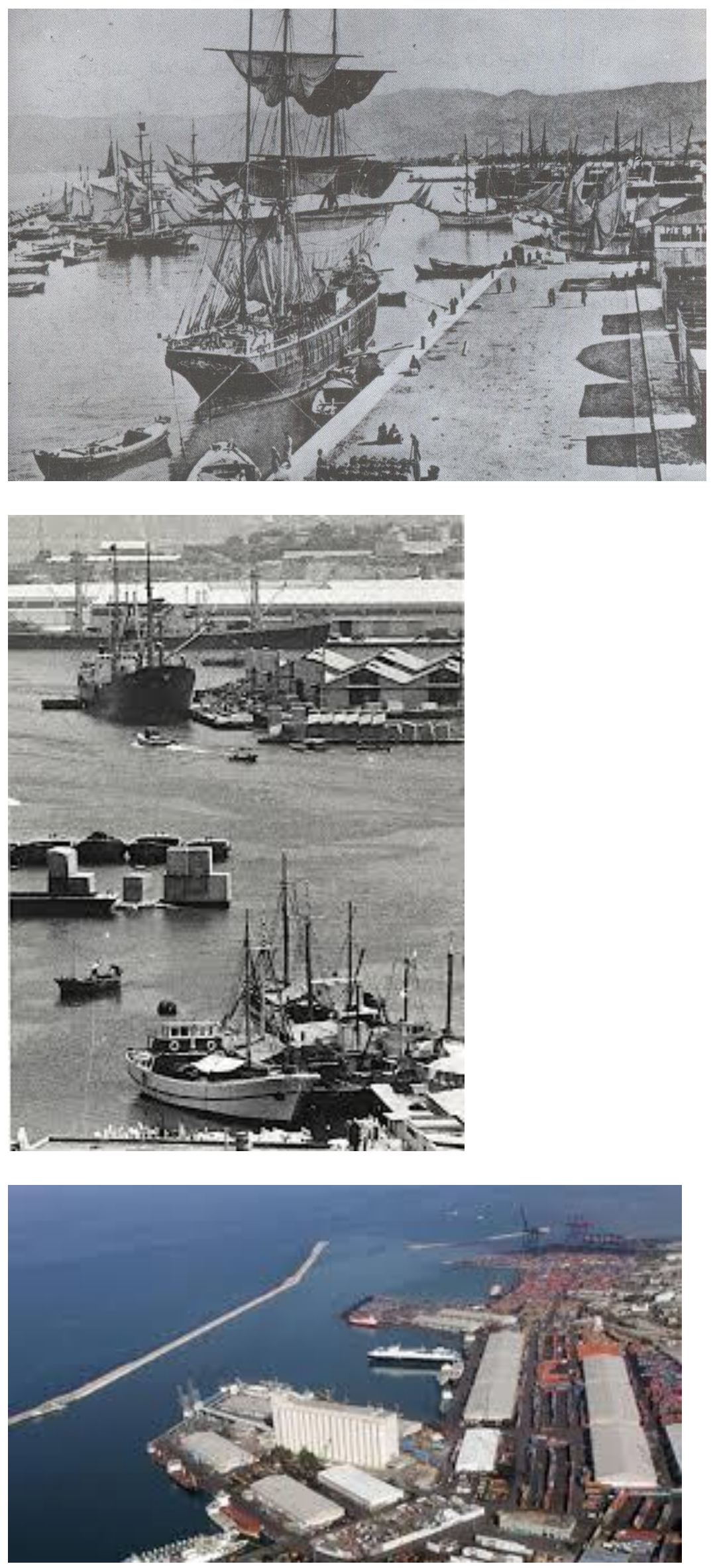

Figure 8. Beirut harbour in the late 19th century to today 


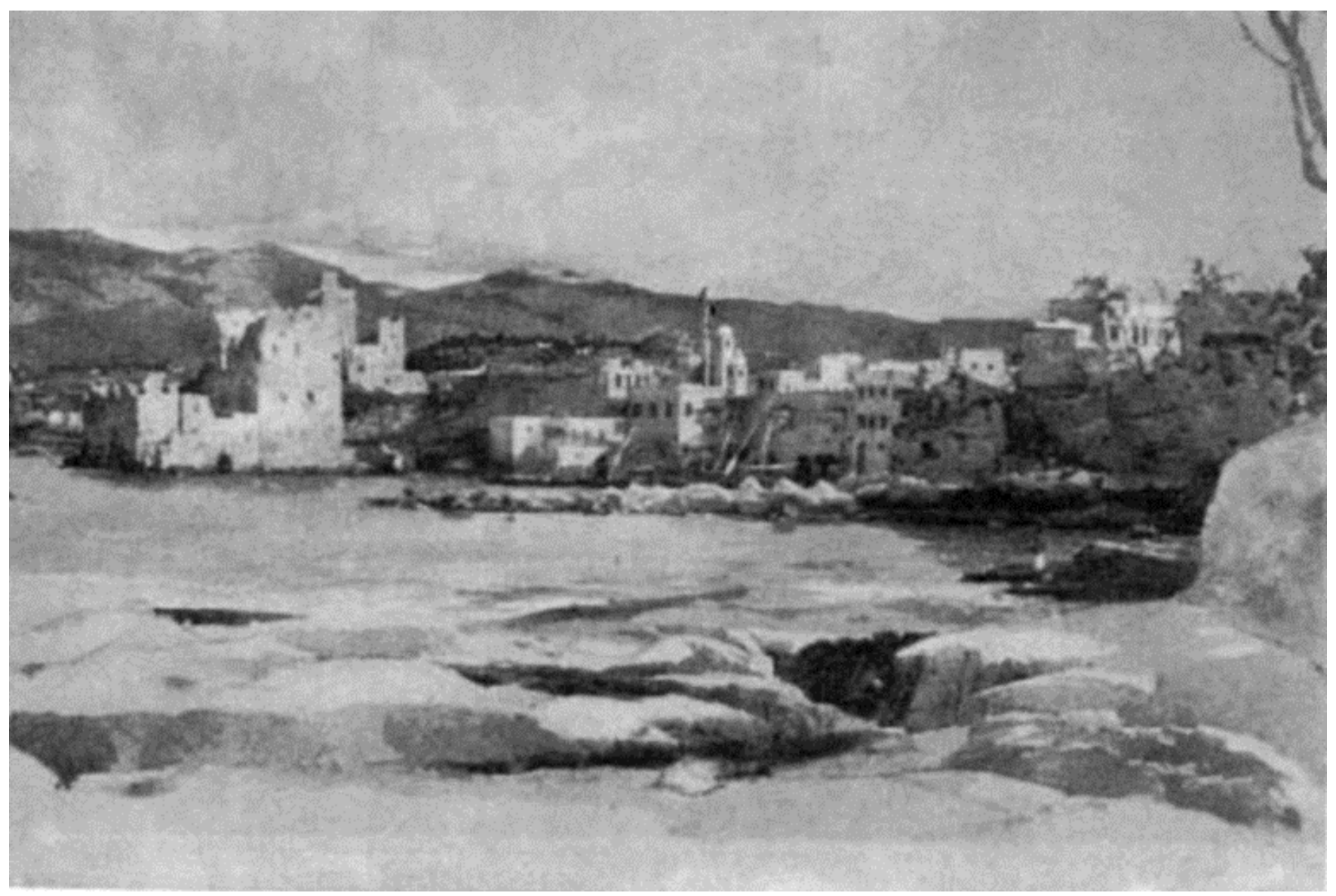

Figure 9. Drawing of Beirut by Max Schmidt in the 1840s, it shows the Island castle (left), mole, and quay (centre), western defences (right). 


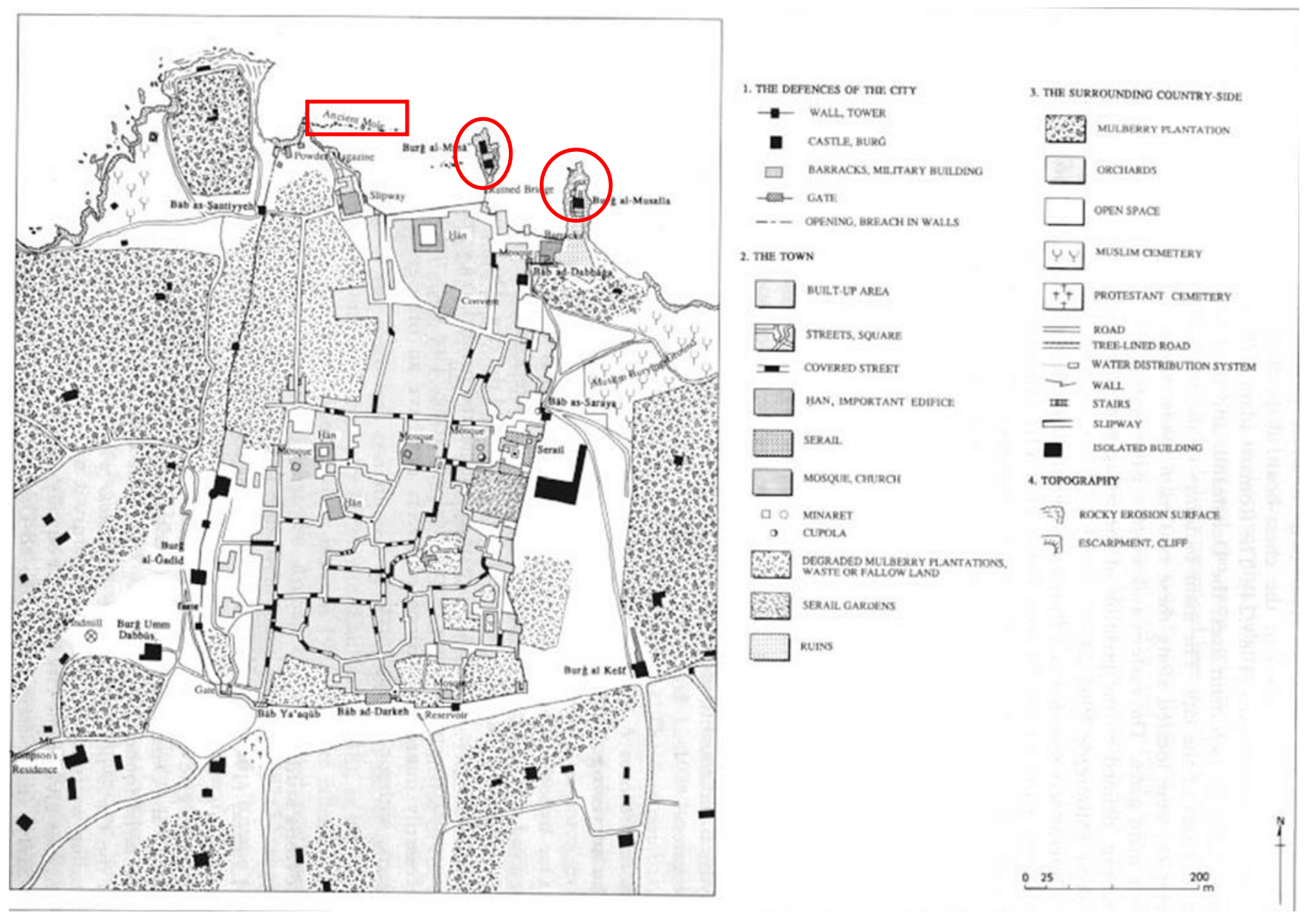

Figure 10. Map of Beirut (1841), in the rectangle is the ancient mole, and in the circles two demolished castle: al-Mina and al-Mussala. 

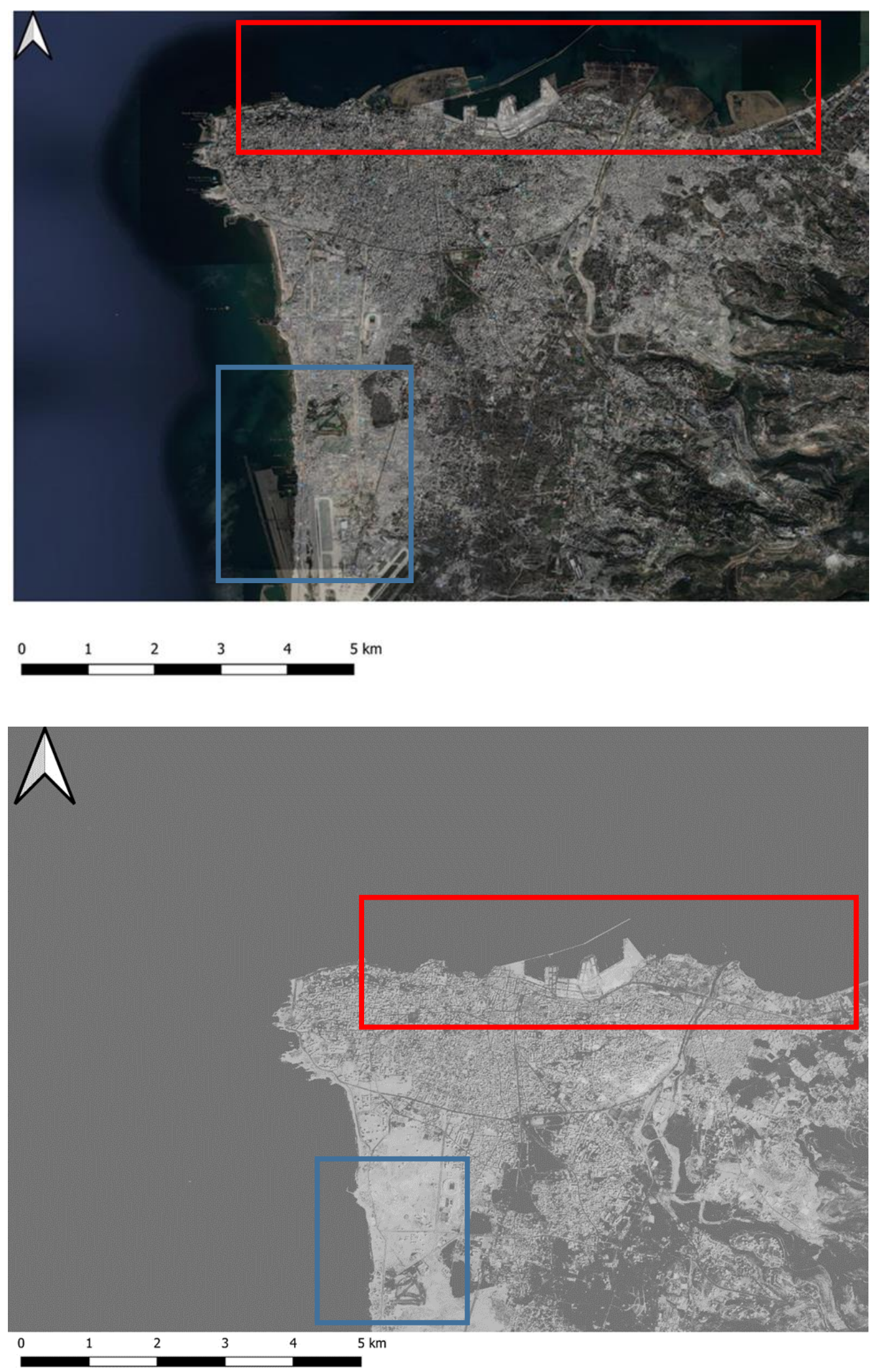

Figure 11. Georeferencing map of Beirut coastline: changes and development between the two maps (Corona 1967-Landsat 2019) of Beirut Coastal area. Red rectangle represents the new harbour; the blue rectangle represents the enlargement of the International airport. 


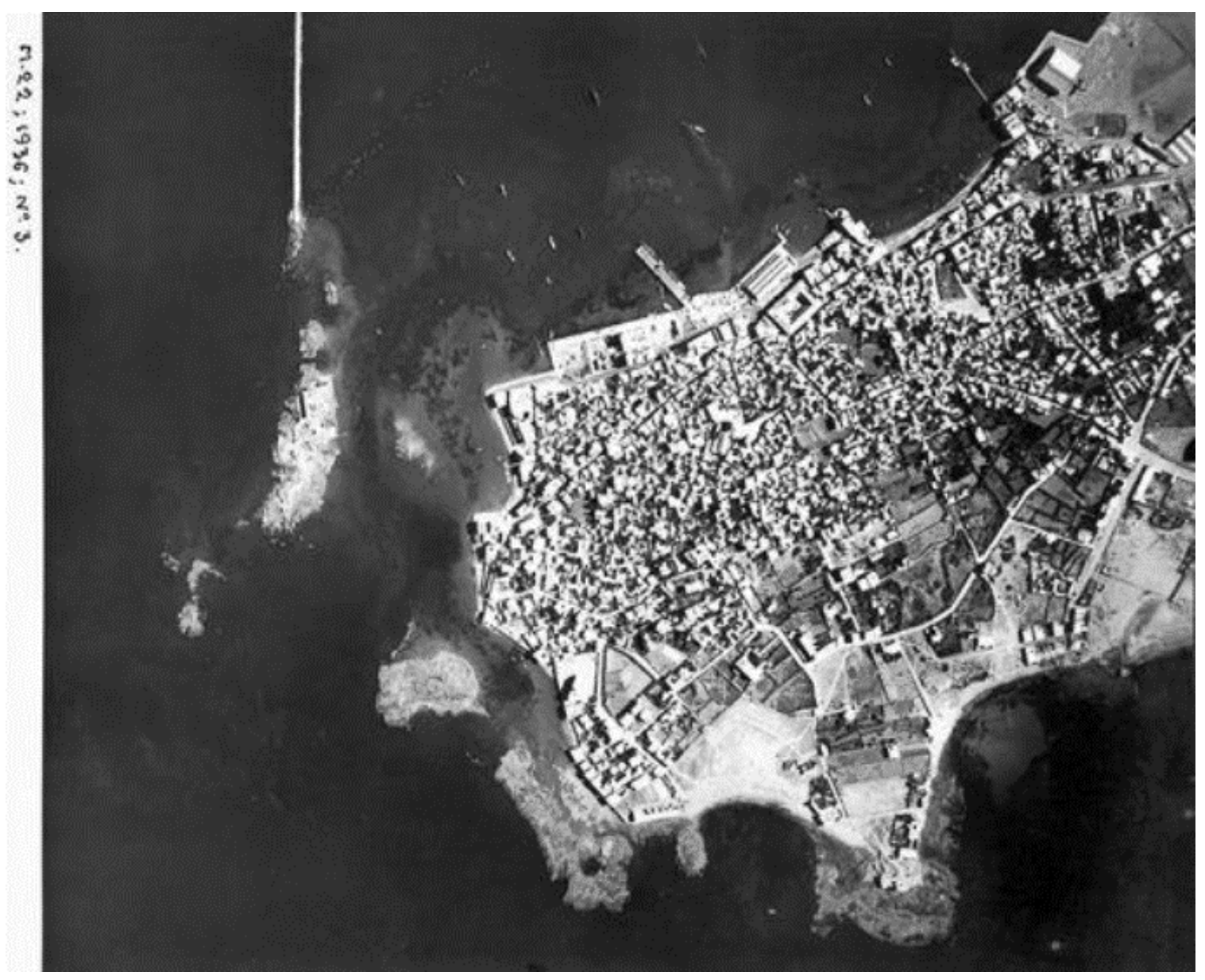

Figure 12. Vertical aerial view of Al-Mina and Tripoli's harbour (Poidebard, Nég. gélatine 13,5 x 16,5 cm. 27 October 1938, 9h05, 2000m). 


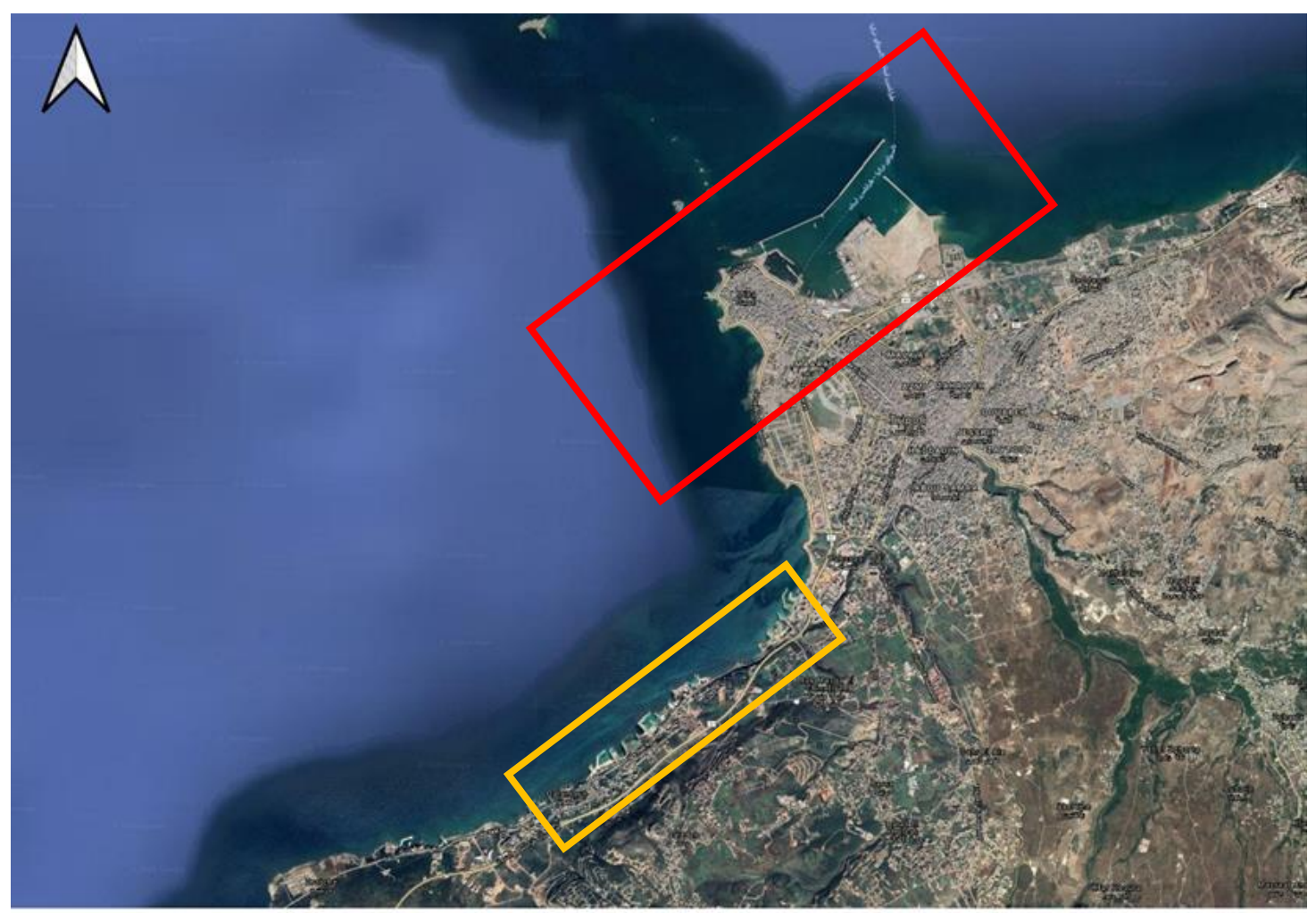

Coastline Tripoli

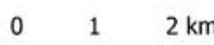

baseMap

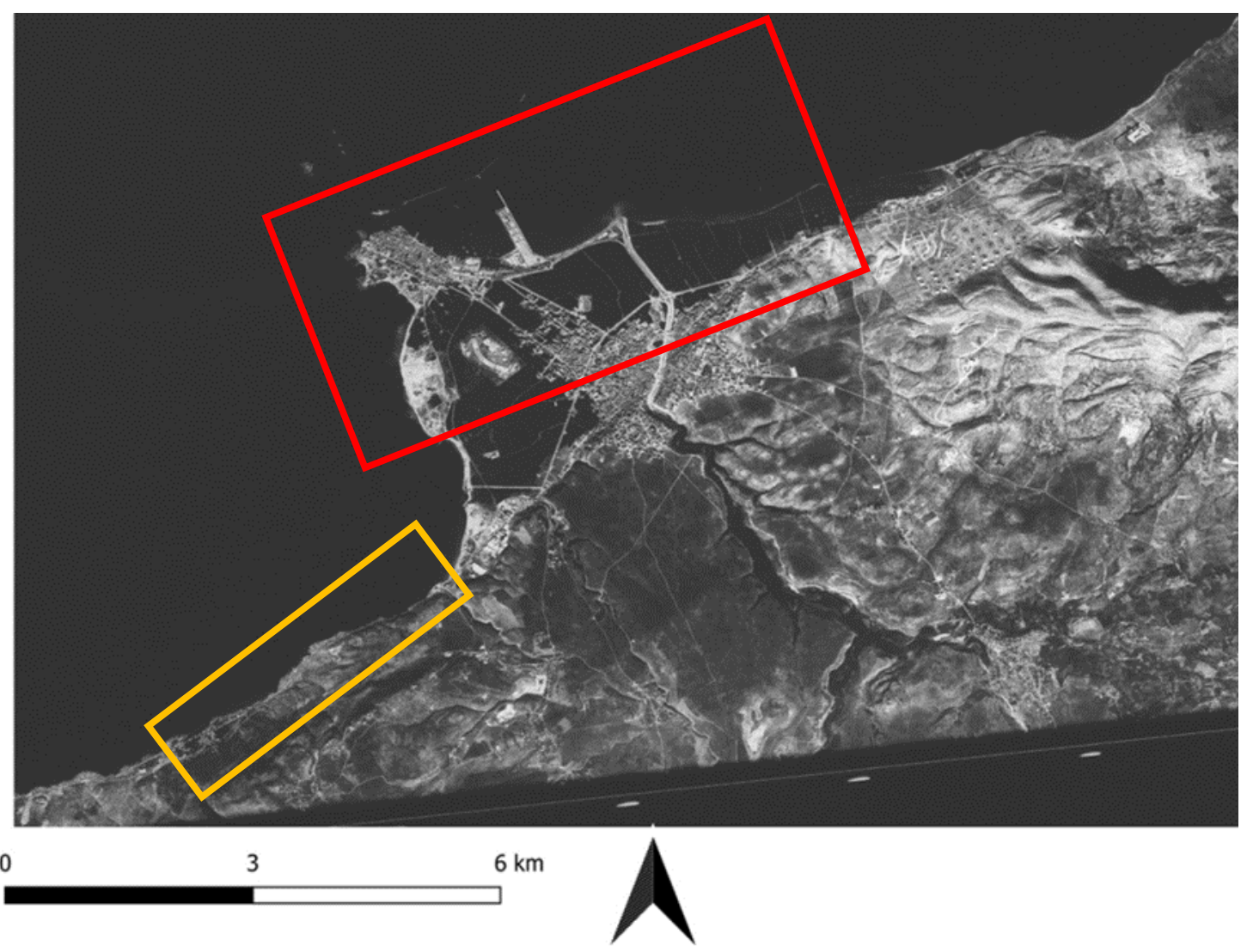

Figure 13. Georeferencing Corona map 1969 in QGIS with Landsat 2019. 


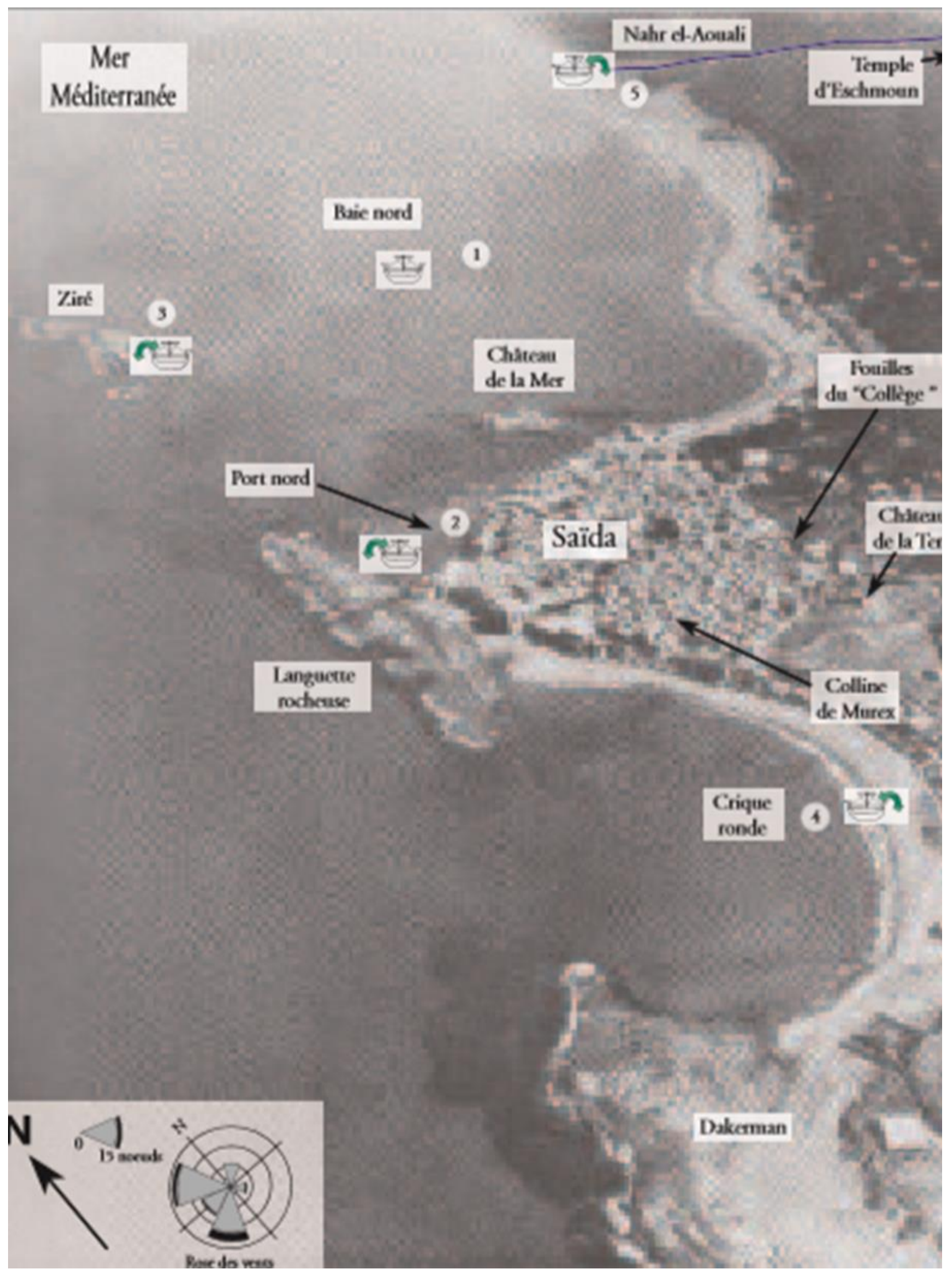

Figure 14. Photo represents the fives natural port of Sidon, taken by Poidbard 1950-51 (Carayon, 2012-13). 

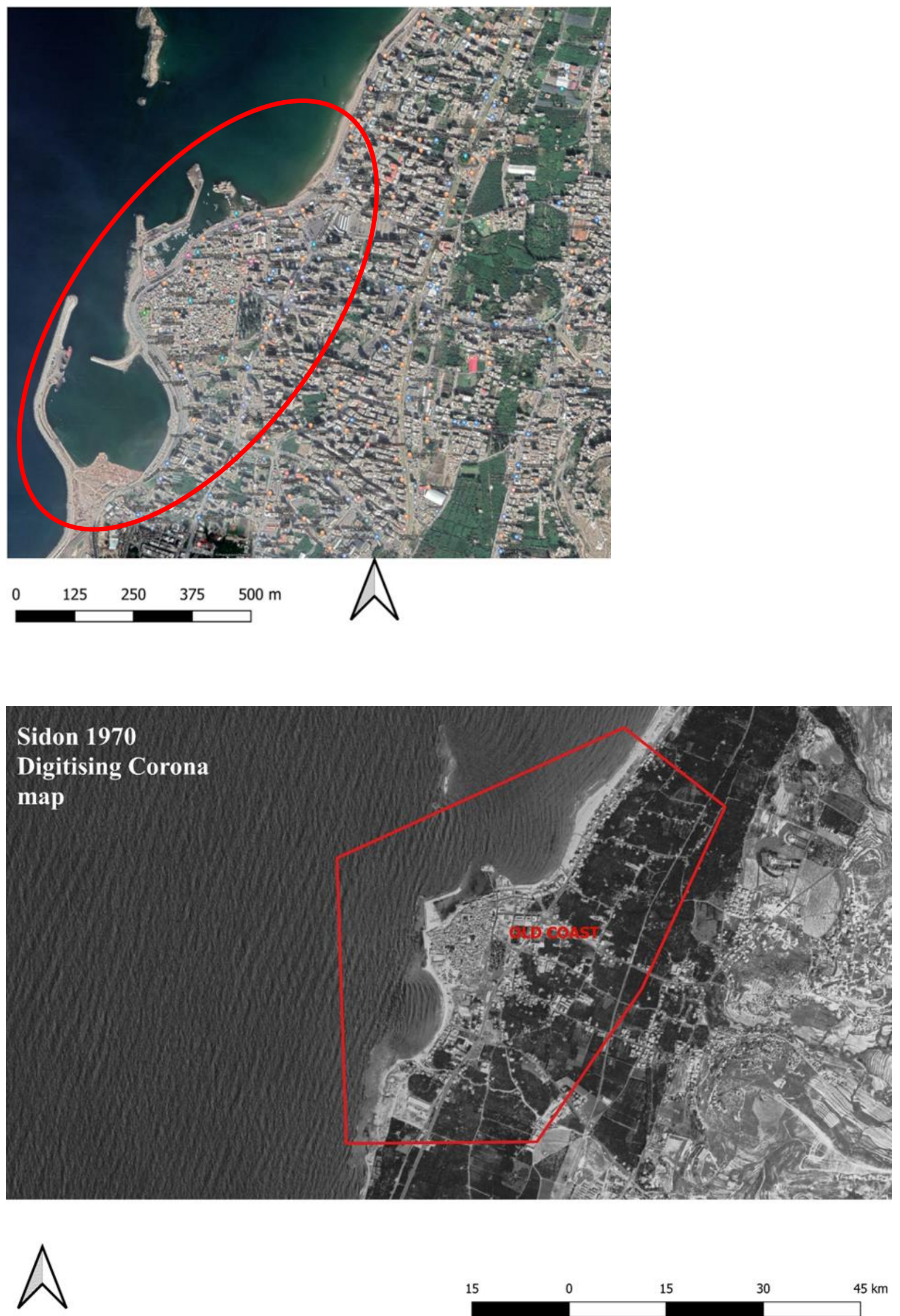

15

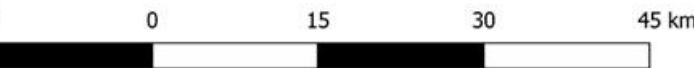

Figure 15. Landsat map 2019, Corona map 1970: modification on over the coastline. 


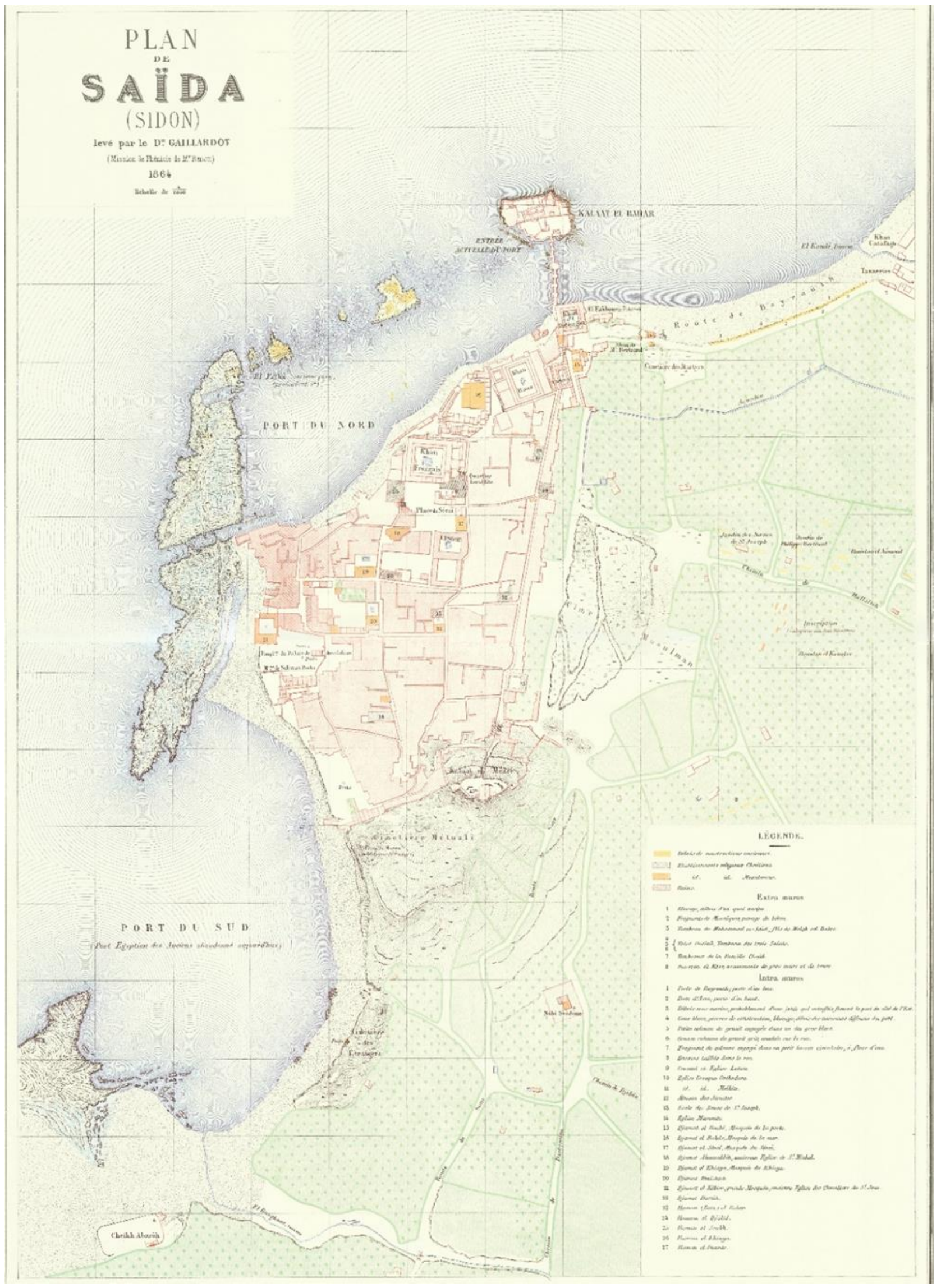

Figure 16. Map of Sidon 1863, Renan. 

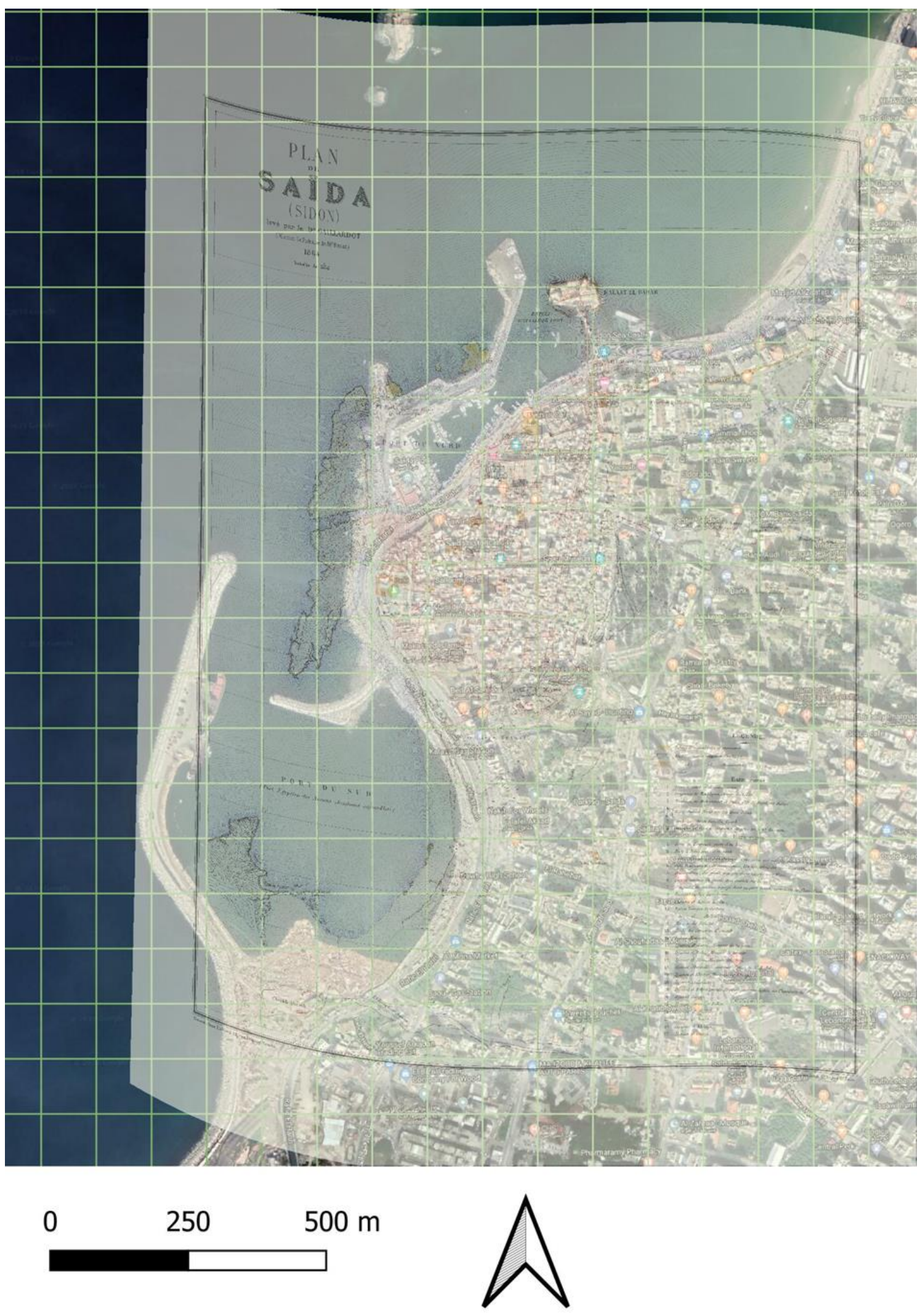

Figure 17. Georeferencing map through the use of gridline: Google Earth image 2019 with ancient map 1863 locate the changes of the years. 